\section{SCIENCE IN CZECHOSLOVAKIA AND YUGOSLAVIA}

A DISCUSSION on "Science in Czechoslovakia", arranged by the Society for Visiting Scientists, was held at the Society's House on February 1. Dr. Jan Masaryk was in the chair, and the speakers were: Prof. J. Bělehrádek, rector of the Charles University, Prague; Dr. J. Cisar, chargé d'affaires, Czechoslovak Embassy ; Prof. E. G. Cox, University of Leeds; Dr. S. C. Dykes; Sir Alfred Egerton; Prof. A. Stampar, rector of the University of Zagreb; and Dr. Nora Wooster.

Dr. Cisar began the discussion by a brief historical outline of the scientific background of Czechoslovakia, during which he mentioned such great names as Kepler, Tycho Brahe, Comenius, who laid the foundations of educational science, Bolzano the mathematician, Purkyně, who coined the word 'protoplasm', Mendel, the founder of modern genetics, Doppler and Ernst Mach. Based on such traditions, modern Czech science has maintained a good international average, which it is hoped would soon be regained and even surpassed. $\mathrm{He}$ left it to Prof. Bellehrádek, who spent the war years under Nazi police supervision, and finally in a concentration camp, to describe the terrible years of Nazi occupation : the closing down of all university buildings as well as the technical colleges and schools, which were the real centres of scientific research ; the imprisonment of thousands of Czech intellectuals and students; and the execution of a number of scientific men and student leaders. All scientific activity was strictly forbidden, and any attempt to teach science was considered as sabotage; laboratories were taken over by professors from the German University in Prague ; clinics and hospitals were put under German direction. Prof. Bělehrádek's own Department of General Biology at the medical faculty was transformed into an Anstalt für Rassenhygiene. Couples intending to marry were examined, measured, weighed and photographed here, and their 'racial' characters determined.

The disorganisation of Czechoslovak science is deep. It is the result of six years of complete cessation of research activities, complete isolation from the outer world, with no possibility of obtaining journals and books from abroad; grave material damage to many laboratories, and the dismantling and removal to Germany of much valuable apparatus.' The situation is further complicated by a serious depletion of academic personnel, and by the greatest influx of students ever experienced. There are to-day 52,000 students at the universities and technical and related schools in Czechoslovakia, out of a population one third the size of that of Great Britain. In Prague alone, there are 3,000 first-year medical students, and 2,000 more in Brno, Bratislava and Králově. Lecturing, practical work and examination absorb the whole time and energy of the teaching staff; dance halls have to be hired for lecturing to the huge classes of students, and practical demonstration is reduced to a minimum. Under such conditions, very little research can be done.

The Czech Government has set up a central plan. ning office in Prague, which is considering these problems; the organisation of scientific research is an important part of its programme. The Office has begun its work, fully aware of the difficulties and the years of hard work ahead, but with a great deal of courage and optimism.
Dr. Stampar, rector of the University of Zagreb (now vice-chairman of the Security Council of the United Nations Organisation), painted a picture of Yugoslovak science not very different from that of Czechoslovakia: wanton destruction of libraries, of laboratories, complete isolation and cessation of work under the mixed domination of Germans and quislings, and a mortality of 10 per cent of the population (and higher still for students) in the struggle for freedom. Yet the liberation has brought the same influx of new students, all eager to learn and work. Cinemas and public halls have been taken over for lecturing, 30,000 students now attending. Their spirit is remarkable; they are orgarising clubs, dining-rooms and dormitories; they help in the repair work of the buildings ; they cut wood to heat the lecture halls and laboratories; they have traced much stolen equipment. Buthere, too, there is a terrible shortage of staff, books and equipment, and it will need all their courage and determination, as well as considerable help from the Allies, to re-organise scientific life.

The other speakers, Sir Alfred Egerton, Dr. Nora Wooster, Prof. E. G. Cox and Dr. Dykes, who had recently visited Czechoslovakia, all stressed the terrible sense of isolation from which scientific workers there are suffering, and their eagerness and urgent need to re-establish contacts. The lack of scientific literature cannot be sufficiently emphasized, and it is hoped that anyone who can will send books, reprints or scientific journals to help fill the gap. Exchange of scientific men will also be of enormous value in helping to re-establish the key position of fundamental research. Owing to economic necessity, the tendency has been towards technological problems, and this, as well as the fact that the younger students have inevitably been infected with Nazi ideology, has tended to discourage a truly scientific outlook.

With reference to Prof. Heyrovský's important work on the polarograph, a suggestion was made that its manufacturers should subsidize research on the subject in Czechoslovakia. (Only one firm had paid any royalties so far to Prof. Heyrovský, and that was a Swedish firm.)

The chairman, Dr. J. Masaryk, wound up the discussion with a brief allusion to the political difficulties which had faced his country after the liberation. He concluded with these words: "Help us to free our souls and the soul of our national genius".

\section{CHROMATOGRAPHIC ANALYSIS}

A MEETING of the Physical Methods Group of the Society of Public Analysts and Other Analytical Chemists was held on February 26 to discuss "Chromatographic Analysis". Four papers were read, two dealing with principles, and two with applications of the method to analytical problems.

Mr. F. A. Robinson described Tswett's classical experiment, in which the pigments of green leaves were separated from one another by pouring a petroleum ether extract of the leaves on to a column of calcium carbonate, and 'developing' with fresh solvent. The method has since been applied not only to the separation of many other coloured substances but also to the separation of numerous colourless substances; but, whereas the position of coloured constituents on a column is self-evident, various 